\title{
EVALUATION OF HELICOBACTER PYLORI IN PATIENTS INVOLVED TO CHRONIC DYSPEPSIA
}

\author{
H. PARSA ${ }^{1}$, G.H. MUSHTARI ${ }^{2}$ \\ 1 Department of Histopathology of Medical Faculty, Taj Private Higher Education Institute, Mazar-i-Sharif, Islamic Republic of Afghanistan \\ 2 Department of Microbiology of Medical Faculty, Balkh University, Mazar-i-Sharif, Islamic Republic of Afghanistan
}

Objective: To determine the frequency of Helicobacter pylori (HP) in patients with chronic dyspepsia referred to private laboratories in Mazar-i-Sharif city in 2019.

Methods: This study is a descriptive cross-sectional study which the sampling method has performed randomly on six private laboratories in Mazari-Sharif city. The population under study consisted people with digestive disorders and a number of them had no any signs and symptoms. Subjects of study were persons that referred to serological and stool testing for HP at private laboratories in Mazar-e Sharif city in the winter season of 2019. Of course, the patients included in this study are mostly those who have been treated with gastritis tablets at one time but have not been cured. The variants of study included gender, age group, presence and absence of signs and symptoms, place of residence. The patients' information was obtained through the patient record book and patient's examination result sheet in which the blood serum and their stool were used for diagnosis.

Results: From 108 patients were recruited for HP study, 53 people were men and 55 people women, who were used for diagnosis serologic and stool tests, which showed that $74 \%$ of patients had positive result for HP and $26 \%$ negative result for HP and these patients were between the ages of $15-65$ in terms of presence and absence of sign and symptoms, $57 \%$ with loss of weight and stomach irritation, $14 \%$ with anorexia, $7 \%$ had headache and vertigo and $22 \%$ had no signs and symptoms.

Conclusions: The present study on 108 who were referred to private laboratories for blood or stool examination were positive for male (39\%) and negative $(13 \%)$, for female $(33 \%)$ were positive and $(15 \%)$ negative. Likewise their age groups were different with the majority of patients being between the ages of $15-25$ and the minority were $56-65$ years. $57 \%$ of patient complaining gastric irritation, severe stomach pain and loss of weight. Keywords: Helicobacter pylori, gastritis, indigestion, dyspepsia, diagnostic tests, sensitivity, resistance.

For citation: Parsa H, Mushtari GH. Evaluation of Helicobacter pylori in patients involved to chronic dyspepsia. Vestnik Avitsenny [Avicenna Bulletin]. 2020;22(1):35-9. Available from: https://doi.org/10.25005/2074-0581-2020-22-1-35-39.

\section{ВЫЯВЛЕНИЕ НЕLICОВАСТЕR РYLORI У БОЛЬНЫХ, СТРАДАЮЩИХ ХРОНИЧЕСКОЙ ДИСПЕПСИЕЙ}

\author{
Х. ПАРСА ${ }^{1}$, Г.Х. МУШТАРИ
}

1 Кафедра гистопатологии, медицинский факультет, Частный институт высшего образования Тадж, Мазари-Шариф, Исламская Республика Афганистан

2 Кафедра микробиологии, медицинский факультет, Балхский университет, Мазари-Шариф, Исламская Республика Афганистан

Цель: установить частоту выявления Helicobacter pylori (HP) у больных с хронической диспепсией, обратившихся в частные лаборатории Мазари-Шарифа в 2019 году.

Материал и методы: настоящее исследование является описательным и межгрупповым, где анализ проведён методом случайной выборки в 6 частных лабораториях Мазари-Шарифа. Обследованные состояли из лиц с нарушениями пищеварения, часть из которых не имела жалоб и симптомов. Объектом исследования явились лица, обратившиеся в 2019 году в лаборатории Мазари-Шарифа как для серологического исследования сыворотки на НР, так и анализа кала на НР. Большинство пациентов, включённых в исследование, лечилось по поводу гастрита, однако без должного эффекта. У больных учитывались такие факторы, как пол, возраст, наличие или отсутствие жалоб и симптомов, место проживания. Указанная информация была получена из карт медицинского обследования и результатов серологического теста сыворотки крови и исследования кала на НP.

Результаты: из 108 обследованных больных мүжчин было 53, женщин - 55. В 74\% случаев тест на НР оказался положительным, в 26\% наблюдений - отрицательным. Возраст пациентов варьировал в пределах 15-65 лет; 57\% жаловались на похудание и дискомфорт в эпигастрии, 14\% - на отсутствие аппетита; $7 \%$ - на головные боли и головокружение, а 22\% больных не предъявляли жалоб и не имели каких-либо симптомов. Заключение: среди обследованных 108 пациентов частота положительных и отрицательных результатов теста на НР среди мужчин была $39 \%$ и 13\% соответственно, а среди женщин это соотношение составило $33 \%$ и 15\%. Большинство больных было в возрасте 15-25, а меньшее число приходилось на возраст 56-65 лет. 57\% больных жаловались на дискомфорт в эпигастрии, интенсивные боли в области желудка и похудание. Ключевые слова: Helicobacter pylori, гастрит, нарушение пищеварения, диспепсия, диагностические тесты, чувствительность, резистентность.

Для цитирования: Parsa H, Mushtari GH. Evaluation of Helicobacter pylori in patients involved to chronic dyspepsia. Вестник Авиценны. 2020;22(1):35-9. Available from: https://doi.org/10.25005/2074-0581-2020-22-1-35-39.

\section{INTRODUCTION}

Helicobacter pylori (HP) is one of the most common chronic infections in the human stomach and has been developed in developing countries. HP is spring like gram negative bacterium similar to Campylobacter, which has a number of active and motive flagella in its one pole, producing urease, catalase and positive oxidase enzymes. HP is a bacterium that infect internal stomach coats. According to the Centers for Disease Control and Prevention 
(CDC) data in 1998, these bacteria are causing for 80 percent of gastric ulcers and 90 percent of duodenal ulcers. They can also cause other stomach problems too [1].

The late $19^{\text {th }}$ century and the early 20th century was a time of great interest and research in gastric physiology and gastric disease [2]. In 1994, the International Agency for Research on Cancer, identified HP as a Group 1 carcinogen for humans and now considered the most common cause of infection-related cancers, with more than $60 \%$ of gastric cancer cases being infected with this bacterium [3].

Gastritis and peptic ulcer are characterized by recurrent pain in the upper abdomen, usually accompanied with bleeding in the gastrointestinal tract. The most common signs and symptoms of HP are dizziness or tiredness, pale skin, burning pain in the abdomen, flatulence, nausea, anorexia, recurrent burping and weight loss [4].

HP pathogenesis develops at pH 7-6 and can't growth under this $\mathrm{pH}$. The gastric mucosa is acid-impermeable and has strong buffering capacity. The $\mathrm{pH}$ of the stomach mucosal surface layer near to the lumen is low (1-2), while the $\mathrm{pH}$ of the stomach mucosal deep layer (near to epithelial cells) up (7.4). HP is founded in the deep layer of stomach mucosa (near to epithelial cells) a place that has physiologic $\mathrm{pH}-7.4$. HP also produce protease, which causes gastric mucosal changes (penetrate the mucosa) and become permeable to acid. HP has strong urease activity that produces ammonia, causing stomach buffering [5].

Numerous studies have tried to identify HP pathogenesis, but it has not been possible yet to link a specific characteristic of the strain to the disease outcome. The antioxidant protein alkylhydroperoxide reductase (AhpC) from HP was found to correlate with the extent of inflammatory damage in tissues [6].

HP is present in the gastric mucosa of less than $20 \%$ of people under 30 ages, but its prevalence increases by $40-60 \%$ in people over 60 years age (including no clinical signs and symptoms). In developing countries the prevalence of infections among young people reaches up to $80 \%$ or more. The transmission of HP from human to human is possible. The source of HP is unclear and the CDC has made no formal recommendation for prevention [7].

Generally, you should maintain hygiene by repeatedly washing your hands and preparing your meals in a healthy and safety manner. If you are diagnosed with HP infection, complete the full course of HP treatment to greatly reduce the risk of recurrence [5].

Many people have had this bacterium in all their lives, while they do not any signs and symptoms. But if the bacterium causes chronic gastric inflammation and remains untreated, it can cause serious complications. These complications can include gastric ulcer and gastric cancer. HP is a major risk factor for some types of gastric cancer. HP is bacterium, that infect the lining of the stomach. It can also cause other stomach problems, including: abdominal pain, abdominal flatulence, nausea, anorexia, and frequent burping and weight loss.

\section{PURPOSE OF RESEARCH}

To determine the frequency of Helicobacter pylori (HP) in patients with chronic dyspepsia referred to private laboratories in Mazar-e-Sharif city in 2019.

\section{MATERIALS AND METHODS}

This study was performed on 108 patients with dyspepsia referred to private laboratories in Mazar-i-Sharif city by their cured- doctors in the last quarter of 2019. This is a descriptive crosssectional study and the sampling method was randomly selected in six private laboratories in Mazar-i-Sharif city. The population under study included people with digestive disorders (indigestion, gastric irritation, headache, vertigo, etc.) and a number of them had no any signs and symptoms. Subjects of study were persons that referred to serological and stool testing for HP at private laboratories in Mazari-Sharif city in the winter season on 2019. Of course, the patients included in this study are mostly those who have been treated with gastritis tablets at one time but have not been cured. The variants of study included gender, age group, presence and absence of signs and symptoms, place of residence. The patients' information was obtained through patient record book and patient's examination result sheet in which the blood serum and their stool were used for diagnosis. There are various methods for diagnose HP patients, in this study due to the lack of economic facilities in our dear country, the method is to provide detailed information at a low cost in a short period of time to accommodate specific conditions or diseases, especially infectious diseases. But it's the most common method in our country. As known HP is the most common infectious diseases that has been a major health problem worldwide for many years. HP infected patients in our beloved country have also been substantially present. On the other hand, international studies suggest that HP is a chronic gastrointestinal infection in some developing countries with high prevalence. Therefore, serum and stool specimens were used to diagnose patients, in which the basis for the detection of antigens in the stool and antibodies in the blood was deduced. Data analysis was done using descriptive statistics by SPSS software (IBM SPSS Statistics 24.0, USA 2017).

\section{RESULTS}

From 108 patients were recruited for HP study, 53 were men and 55 women. Who were used for diagnosis of HP their serologic tests and stool tests, which showed that $74 \%$ of patients had positive result for $\mathrm{HP}$ and $26 \%$ negative result for $\mathrm{HP}$ and these patients were between the ages of 15-65 in terms of presence and absence of signs and symptoms, 57\% with low weight and stomach irritation, $14 \%$ with anorexia, $7 \%$ had headache and vertigo and $22 \%$ had no signs and symptoms.

Table 1 shows that out of total 108 people studied, $74 \%$ were with positive and $26 \%$ with negative result.

Table 2 shows that in all studied subjects, the most common signs and symptoms were in all patient weight loss, burning and stomach pain, and the least symptoms were headache and vertigo, and $22 \%$ others were without signs and symptoms.

Table 3 shows that most of the study subjects were in the age group of $15-25$ and the least number of them were in the age group of 56-65.

\section{Discussion}

In the United States, doctors rarely prescribe the tests needed to diagnose HP unless you have signs and symptoms of the infection. If you have any suspicious signs and symptoms, be sure to see your doctor for further examination. Many signs and symptoms of HP infection are common with gastric diseases such as gastroesophageal reflux disease (GERD). It is important to correctly diagnose your illness by your doctor until you treated well. If your test for HP infection is positive, sooner you start treatment for HP that is better for you. Natural remedies may not harm you, but it has not been proven to 
Table 1 Descriptive statistic of obtained result from serologic and stool

\begin{tabular}{|c|c|c|c|c|c|}
\hline & Result & Frequency & Percent & Valid percent & $\begin{array}{c}\text { Cumulative } \\
\text { percent }\end{array}$ \\
\hline \multirow{3}{*}{ Valid } & Positive & 80 & 74.1 & 74.1 & 74.1 \\
\hline & Negative & 28 & 25.9 & 25.9 & 100.0 \\
\hline & Total & 108 & 100.0 & 100.0 & \\
\hline
\end{tabular}

Table 2 Descriptive statistics of participators on base of existence and nonexistence of clinically symptoms

\begin{tabular}{|c|c|c|c|c|c|}
\hline & Signs \& symptoms & Frequency & Percent & Valid percent & Cumulative percent \\
\hline \multirow{5}{*}{ Valid } & Anorexia & 15 & 13.9 & 13.9 & 13.9 \\
\hline & Headache and vertigo & 7 & 6.5 & 6.5 & 20.4 \\
\hline & Loss of weight, burning and stomach pain & 62 & 57.4 & 57.4 & 77.8 \\
\hline & No symptoms & 24 & 22.2 & 22.2 & 100.0 \\
\hline & Total & 108 & 100.0 & 100.0 & \\
\hline
\end{tabular}

Table 3 Descriptive statistics of participators on base of age

\begin{tabular}{|c|c|c|c|c|c|c|}
\hline & Age range & Frequency & Percent & Valid percent & Cumulative percent \\
\hline & $15-25$ & 43 & 39.8 & 39.8 & 39.8 \\
\hline \multirow{3}{*}{ Valid } & $26-35$ & 34 & 31.5 & 31.5 & 71.3 \\
& $36-45$ & 17 & 15.7 & 15.7 & 87.0 \\
& $46-55$ & 10 & 9.3 & 9.3 & 96.3 \\
& $56-65$ & 4 & 3.7 & 3.7 & 100.0 \\
\hline
\end{tabular}

eliminate this infection. Therefore, the most common examination used to diagnose HP is the following: endoscopic biopsy; through blood antibody tests - by PCR, by urease breathing test, by ELISA; stool antigen test. The diagnosis and treatment of HP is made by the following diagnostic tests: clinically detecting HP infection requires a diagnostic test that is inexpensive, accurate and accessible. Diagnostic methods can be divided into two categories: direct and indirect. Direct methods include invasive techniques, including endoscopy, biopsy specimen preparation, staining of specimens, and urease activity detection. Indirect methods include urease breathing tests and serologic tests. Endoscopy is a non-surgical procedure used to examine a person's digestive tract. Using an endoscope, a flexible tube with a light and a camera attached to it, your doctor can view your digestive tract images on a color TV monitor. Some gastrointestinal specialists use this method to detect stomach and bowel diseases. In this method, biopsy is performed to confirm the presence or absence of HP in tissue. It should be noted that, like other diagnostic methods, all antibiotics should be avoided prior to examining. It should not be consumed six hours before endoscopy water and food. A complete endoscopy takes about 15 minutes. In the endoscopic room, the patient is given intravenous anesthetics. The patient's mouth is also sprayed with topical anesthetics. After this, a thin, flexible tube is inserted into the patient's mouth which its thickness is similar to the small finger diameter. However, many patients experience discomfort during examining. When the endoscopic head enters to the stomach and duodenum with the help of a specialist, the endoscopic camera will show existing of erosion, scars, etc. Also during endoscopy, tissue samples are taken and the specimens can be stained with the help of a gram stain and viewed under a microscope, or tests such as Gemsa and silver staining that can be used to better detect infection.
Although HP is not a bacterium that directly attacks the host mucosal tissues, but it stimulates the host immune system due to lipopolysaccharide secretion. Serological tests have been suggested as non-invasive methods for the diagnosis of HP infection and their accuracy is acceptable. These kits contain pure bacterial antigens. It should be noted that kits that contain different antigens have higher sensitivity and specificity than those that use only one antigen. Most patients with HP infection have significant levels of specific antibodies in their serum. Anti-HP antibodies have different classes. These antibodies are IgA and IgG in chronic infection and IgM in acute infection. The methods used to identify specific antibodies against HP include agglutination, complementation and fixation as well as ELISA. ELIZA is the most common technique used in many laboratories. This is a fast, inexpensive, reusable, easy-to-use method. HP cause's chronic infections, so IgG antibody titers should be measured. IgG does not appear until several weeks after infection and does not decrease its titers until six months after eradication. Assessment of antibody titers is very useful for detecting infection eradication after treatment. Specific antibody titers decrease slowly with eradication of infection.

The culture of HP has been associated with negative results through stool samples. Therefore, researchers have concluded that this bacillus loses its life in the gut due to bile salt and competing factors. For culture, it is necessary to put the stool sample in a suitable buffer, then centrifuge the suspended sample and then culture it in a specific medium, also can use from the PCR by using from the stool sample due to identify HP. The PCR method does not require bacillus to be alive and therefore enjoys more sensitive to culture. In America today, a special method called stool antigen assay is used to detect HP. This test is used to diagnose and follow-up of treatment, has a sensitivity of $95-90 \%$, but results in 48 hours. The 
best exam for follow-up treatment is 4-6 weeks after treatment, if the PPI is given, the sensitivity of the test will decrease.

In this test, a biopsy of the stomach is taken in a small container containing agar gel + urea. If HP is present, the urea in the medium will break down into ammonia and carbon dioxide, which will then acidify the environment and the yellow of medium due to acidifying of medium change to red color. Of course, this interaction takes 2-24 hours.

Currently, the isolation of HP from tissue specimens as a good diagnostic method has been proposed and routinely performed. Endoscopic tissue fragments must be prepared for culture as soon as possible for detection of HP because survival of this bacterium is reduced by oxygen. Transport environments are used to transport and maintain the sample. Most are added bloodstream to the environments and contain antibiotics. Selected environments of HP include Colombia agar, Chegilat agar, Campylobacter selective agar, Brucella agar, which should be supplemented with antibiotics. HP is sensitive to atmosphere oxygen concentration and grows only under micro aerobic conditions at temperatures of $33-40^{\circ} \mathrm{C}$ and for better growth a gaseous atmosphere containing $5 \%$ oxygen, $5 \%$ carbon dioxide, $2 \%$ hydrogen and $88 \%$ nitrogen. After transferring to the desired environments, the plate should be incubated in the micro aerobic conditions for at least 4 days. It usually takes 3 to 5 days for $\mathrm{HP}$ colonies to appear on the culture environment. These colonies are translucent and spherical in diameter of $1-2 \mathrm{~mm}$. Although this method is a common method of isolating many infectious agents, it is difficult to do so because of its high cost and low growth rate, and the advantage of culturing apart from its sensitivity and specificity is that which allows the bacterial resistance to antibiotics be determined. HP culture is usually used for initial diagnosis. The false-negative results are high in this method, two-week high uptime is required for bacterial growth. Another problem is that which this bacterium sometimes turns into a coccid form in culture.

As mentioned, there are many tests and methods available to diagnose HP at present, but due to lack of economic and medical facilities in our dear country Afghanistan the least costly and affordable method available here. We used blood and stool for testing, base of our detection was surface antigen availability in the stool and blood HP antibody, sensitivity and specificity of this method is less than $32 \%$ for the serologic procedure. And also the likelihood of false positive results is possible [8]. The study has shown that the diagnostic value of this method is less than other methods, although it is commonly used [9].

Biopsy specimens can also be used for polymerase chain reaction (PCR) based molecular testing or for culture. Because everything in the stomach must eventually appear in the stool, stool antigen tests have been devised and tests using monoclonal HP antibodies have proved similar in sensitivity and specificity to the urea breath test [10].

Today, medical devices designed to detect breath ammonia originally produced in the stomach are in use clinically to detect infection with the gram negative bacterium HP, an important human pathogen that despite a decline in prevalence still infects approximately $50 \%$ of humans worldwide. HP infection is the most common causative agent of gastritis, peptic ulcers and gastric cancer [11].

In a study in India, respiratory urease test had a specificity and sensitivity of $31 \%$ and $32 \%$, respectively [9], but due to the high cost of rapid urease testing, the histologic and microbiological method are usually recommended in the first steps of diagnosis [12]. This is especially important in populations where atrophic gastritis is present and in those taking acid suppressing medicines such as $\mathrm{H} 2-$ receptor antagonists. In those populations the proportion of false positive or false negative tests is often clinically possible [13].

Studies on the value of the diagnosis of respiratory urease have been contradictory, but overall, they have been shown to be more sensitive and specific than fecal antigen and serology antibody tests. In our study, this test was less sensitive than serology but more specific. Economically studies have shown that performing respiratory urease testing and its treatment is more cost-effective than performing serology-treatment. However, there are no recommendations for this test to identify HP as a diagnostic standard $[12,14]$. In the case of fecal antigen testing for HP infection, the quality of the test depends on the antigen selected for its detection, and the use of polyclonal antibodies has a poor diagnostic value compared to monoclonal antibodies. Genetic differences in the strains of this bacterium led to geographical differences in the diagnostic value of this test [15]. In our study, the sensitivity of the serology was more than the fecal antigen, but a study in Pakistan showed that the fecal antigen and the serology had the same sensitivity for diagnosis [16]. Studies have shown that fecal antigen testing has a higher diagnostic value if the prevalence of HP infection is more than $41 \%$ in a population [9].

\section{CONCLUSION}

The present study on 108 who were referred to private laboratories for blood or stool examination were positive for male $(39 \%)$ and negative $(13 \%)$, for female (33\%) were positive and (15\%) negative. Likewise their age groups was different with the majority of patients being between the ages of 15-25 and the minority were $56-65$ years. $57 \%$ of patient complaining gastric irritation, severe stomach pain and loss of weight.

\section{REFERENCES}

1. Ali E, Mehdi F, Mahdad BR. Diagnose of Helicobacter pylori infection in stool specimens by use C gene on PCR-ELISA test. Medical Sciences Journal. 2010;13(4):61-67.

2. Graham DY. History of Helicobacter pylori, duodenal ulcer, gastric ulcer and gastric cancer. World J Gastroenterol. 2014;20(18):5191-204.

3. Seyamak Kh, Mahshid TT, Elnaz S, Hadi T, Shahbaz N. Accuracy of diagnostic tests for Helicobacter pylori infection. Journal of Ardabil University of Medical Sciences. 2012;4:258-64.

4. Naimi HM. Medical Microbiology. Kabul, Afghanistan: Azim; 2014. p. 237-9.

5. Obaidullah O. Medical Microbiology. Kabul, Afghanistan: Azim; 2013. p. 73-6.
6. Huang $\mathrm{CH}$, Chuang MH, Lo WL, Wu MS, Wu YH, Wu DC, et al. Alkylhydroperoxide reductase of Helicobacter pylori as a biomarker for gastric patients with different pathological manifestations. Biochimie. 2011;93)11:(15-23.

7. Mahdi R, Mahdi AM, Mahnaz T, Jawaiz P. Medical Microbiology. Tehran, Iran: Asar Sobhan; 2016. p. 286-8.

8. Baqai R, Qureshi H, Arian G, Mehdi I. Diagnostic efficacy of stool antigen test (HPSA), CLO test and serology for the detection of Helicobacter pylori infection. J Ayub Med Coll Abbottabad. 2003;15(4):34-6.

9. Peng NJ, Lai KH, Lo GH, Hsu PI. Comparison of noninvasive diagnostic tests for Helicobacter pylori infection. Med Princ Pract. 2009;18(1):57-61. 
10. Miftahussurur M, Yamaoka Y. Diagnostic methods of Helicobacter pylori infection for epidemiological studies: critical importance of indirect test validation. Biomed Res Int. 2016;2016:4819423. Available from: https://doi. org./10.1155/2016/4819423.

11. Megraud F, Floch P, Labenz J, Lehours P. Diagnostic of Helicobacter pylori infection. Helicobacter. 2016;21(Suppl. 1):8-13.

12. Faruqui AN, Majid, U, Ahmad L, Khalil M, Hassan MU. Helicobacter pylori stool antigen test (HpSA) for the diagnosis of gastric infection. J Coll Physicians Surg Pak. 2007;17(6):31691.

13. Kwon YH, Kim N, Lee JY, Choi YJ, Yoon K, Hwang JJ, et al. The diagnostic validity of citric acid-free, high dose (13) C-urea breath test after Helicobacter pylori eradication in Korea. Helicobacter. 2015;20(3):159-68.
14. Malik GM, Mubarik M, Kadla SA. Helicobacter pylori infection in endoscopic biopsy speciments of gastric antrum: Laboratory diagnosis and comparative efficacy of three diagnosis test. J Diagnostic and Therapeutic Endoscopy. 1999;6(1):9-25.

15. Amoueian S, Mordi Moghaddam F, Esmailzadeh A, Attaranzadeh A, Rahimi M, Montazer M. Diagnostic accuracy of Helicobacter stool antigen in dyspeptic patients before eradication therapy. Medical Journal of Mashhad University of Medical Sciences. 2011;54(1):13-8.

16. McNulty CA, Lehours P, Megraud F. Diagnosis of Helicobacter pylori infection. Helicobacter. 2011;16(1):10-81.

\section{(7) author information}

Parsa Hamed, Doctor of Medical Sciences, Assistant Professor, Lecturer at Department of Microbiology in Medical faculty of Balkh University ORCID ID: 0000-0001-9258-6114

Tel.: +93 (707) 740077

E-mail: Hparsa2008@gmail.com

Mushtari Ghullam Haidar, Doctor of Medical Sciences, Lecturer at Department of Histopathology in Medical faculty, Taj Private Higher Education Institute

ORCID ID: 0000-0001-9116-7137

Tel.: +93 (799) 266497

E-mail: Mdhghm786@gmail.com

Information about the source of support in the form of grants, equipment, and drugs

The authors did not receive financial support from manufacturers of medicines and medical equipment

Conflicts of interest: The authors have no conflicts of interest

\section{ADDRESS FOR CORRESPONDENCE:}

\section{Parsa Hamed}

Doctor of Medical Sciences, Assistant Professor, Lecturer at Department of Microbiology in Medical faculty of Balkh University

1701, Islamic Republic of Afghanistan, Mazar-i-Sharif, Masoud Road Tel.: +93 (707) 740077

E-mail: Hparsa2008@gmail.com

\section{AUTHOR CONTRIBUTIONS}

Conception and design: MGH

Data collection: $\mathrm{PH}$

Statistical analysis: $\mathrm{PH}$

Analysis and interpretation: $\mathrm{MGH}$

Writing the article: $\mathrm{PH}, \mathrm{MGH}$

Critical revision of the article: $M G H$

Overall responsibility: $\mathrm{MGH}$

$\begin{array}{lr}\text { Submitted } & 09.01 .2020 \\ \text { Accepted } & 26.03 .2020\end{array}$

\section{СВЕДЕНИЯ ОБ АВТОРАХ}

Парса Хамед, Доктор медицины, доцент, преподаватель кафедры микробиологии, медицинский факультет, Университет Балха ORCID ID: 0000-0001-9258-6114

Тел.: +93 (707) 740077

E-mail: Hparsa2008@gmail.com

Муштари Гулам Хайдар, Доктор медицины, доцент, преподаватель кафедры гистопатологии, медицинский факультет, Частный институт высшего образования Тадж

ORCID ID: 0000-0001-9116-7137

Тел.: +93 (799) 266497

E-mail: Mdhghm786@gmail.com

Информация об источнике поддержки в виде грантов, оборудования лекарственных препаратов

Финансовой поддержки со стороны компаний-производителей лекарственных препаратов и медицинского оборудования авторы не получали

Конфликт интересов: отсутствует

\section{АДРЕС ДЛЯ КОРРЕСПОНДЕНЦИИ:}

Парса Хамед

Доктор медицины, доцент, преподаватель кафедры микробиологии, медицинский факультет, Университет Балха

1701, Исламская Республика Афганистан, Мазари-Шариф, шоссе Масуд Тел.: +93 (707) 740077

E-mail: Hparsa2008@gmail.com

\section{ВКЛАД АВТОРОВ}

Разработка концепции и дизайна исследования: МГХ

Сбор материала: ПХ

Статистическая обработка данных: ПХ

Анализ полученных данных: МГX

Подготовка текста: ПХ, МГХ

Редактирование: МГX

Общая ответственность: МГX

$\begin{array}{ll}\text { Поступила } & 09.01 .2020 \\ \text { Принята в печать } & 26.03 .2020\end{array}$

